\title{
Does context matter? Analysing structural and individual factors of member commitment in sport clubs
}

\author{
Torsten Schlesinger ${ }^{1}$ and Siegfried Nagel ${ }^{1}$ \\ ${ }^{1}$ University of Bern, Switzerland
}

\begin{abstract}
This article addresses factors that influence member commitment in sport clubs. Based on the theory of social action and the economic behaviour theory, it focuses not only on individual characteristics of club members but also on the corresponding structural conditions of sport clubs. Accordingly, a multilevel framework is developed for explaining member commitment in sport clubs. Different multilevel models were estimated in order to analyse the influences of both the individual and corresponding context level in a sample of $n=1,699$ members of 42 Swiss and German sport clubs. The multilevel analysis permitted an adequate handling of hierarchically structured data. Results of these multilevel analyses indicated that the commitment of members is not just an outcome of individual characteristics such as strong identification with their club, positively perceived (collective) solidarity, satisfaction with their sport club, or voluntary engagement. It is also determined by club-specific structural conditions: commitment proves to be more probable in rural sport clubs and clubs that explicitly support sociability. Furthermore, cross-level effects in relation to member commitment were also found between the context variable sociability and the individual variable identification.
\end{abstract}

Keywords: sport clubs, commitment of members, interest organisation, multilevel analysis

\section{Introduction}

In times of social crisis, third-sector organisations, including sport clubs, are discussed and instrumentalised as an alternative means of compensating for various problems (e.g. financial crisis, shortage of public resources, reduction in social benefits provided by the state; Jütting, von Bentem \& Oshege, 2003). It follows that sport clubs as non-profit organisations with their organisational logic based on selforganisation are not simply a marginal phenomenon within our society, rather they act as an essential alternative to the market and the state, and fulfil a wide range of socio-political functions (Gratton, Liu, Ramchandani \& Wilson, 2012; Nichols \& James, 2008). Accordingly, sport clubs are on the political agenda more and more often, and are being systematically involved in government plans in order to achieve desirable outcomes such as sport supply, the integration of various target groups, and promoting health and welfare within a community, region, or society (e.g., Green, 2008; Houlihan \& Green 2009; Nichols \& James, 2008). 
Currently, however, sport clubs are themselves in a crisis and are often considered in forecasts of the future to be an obsolete model in terms of the erosion of traditional community-related norms and forms of solidarity, which is attributed particularly to far-reaching changes in values and an increasing demand for individualistic self-fulfilment (Putnam, 2000). In recent decades, sport clubs have lost their monopoly on the market for sport-related services and are increasingly having to compete with other sport providers. As a result, more and more sport clubs are confronted with increasing fluctuations in membership or stagnating membership figures, so that sport clubs are at risk in terms of their ability to survive. Thus examples of negative tendencies can be observed in which decreasing membership figures lead to the disbanding of training groups, departments or entire sport clubs. Although the destabilisation of membership numbers in sport clubs has been a subject of discussion in sport club research and sports policy for some time now, and despite such crisis-like scenarios, sport clubs continue to be the most important institution to offer popular sports. Nevertheless, the current Swiss sport club report reveals that long-term membership is now a problem for about $40 \%$ of sport clubs (Lamprecht, Fischer \& Stamm, 2012), and similar trends can also be observed in other countries (e.g., Breuer, Wicker \& Feiler, 2014; Nichols et al., 2005; Scheerder \& Vos, 2010). However, encouraging more commitment among members is becoming a major management problem for sport clubs, and a clear understanding of which factors trigger and sustain long-term member commitment would help managements to tackle this issue more successfully. Furthermore, stability of club membership is an important precondition that sport clubs can fulfil their social functions.

A closer look at recent findings from various sport club reports reveals that not all clubs are suffering equally from a decrease in membership numbers. Some - because of their specific situational and structural conditions - have few problems with member fluctuation, whereas others show considerable declines (Lamprecht et al., 2012). Thus, it can be assumed that the commitment of members may also depend on the distinctive conditions within each sport club (e.g. its size, member structure, strategic orientation, etc.). Because commitment of members usually occurs within a specific organisational context, the unique characteristics of the organisation itself should also be considered (Penner, 2002). It can be seen that member fluctuation is not only an individual problem. Moreover, different intra-organisational structures in sport clubs may lead to differences in the collectively shared action orientations that serve as the basis for stable membership. This leads to the question, which structural conditions help to stabilise club membership? In particular, organisational changes such as an increased service orientation combined with giving access to non-members (as customers) may lead to greater divergences between individual (member) and collective (club) interests (e.g. Klenk, 2011). Such changes increasingly erode members' solidarity and commitment to the club (e.g. Horch, 1998; Nagel, 2006b). 
Although there have been calls for linkages between individual and corresponding structural data within sport organisation research for some time (e.g. Nagel, 2007; Wicker \& Hallmann, 2013), these have yet to be implemented consistently. As a result, we still know little about the influences of factors from different levels as well as their interplay on member commitment. In both sport sociology and sport management research, only a few studies currently relate contextual factors to individual behaviour in a suitable way (in sport participation research: Hallmann, Wicker, Breuer \& Schüttoff, 2011; Hallmann, Wicker, Breuer \& Schönherr, 2012; van Tuyckom \& Scheerder, 2010; Wicker, Hallmann \& Breuer, 2012; 2013; player salaries in baseball teams: Todd, Crook \& Barilla, 2005; member action in sport clubs: Schlesinger \& Nagel, 2013a; 2013b). The aim of the following analysis is to investigate which individual factors, along with their corresponding structural factors, as well as the probable interactions between the two, are responsible for long-term club memberships.

The article is structured as follows: The theoretical framework starts with some general reflections on the relevance of social context conditions associated with individual action. These general assumptions are used to develop a specific multilevel framework for explaining the commitment of members in sport clubs. The methods section then describes the data collection and the appropriate analysis of hierarchical data structures. This is followed by the presentation of results and their final discussion.

\section{Theoretical framework}

Why consider the social context?

Member commitment can be seen as a social action and as a decision to either continue or quit club membership. Accordingly, we want to start with some general reflections on the relevance of social conditions associated with individual action. When dealing with questions of individual action or behaviour in sport-related contexts, analyses are often reduced to a focus on individual characteristics. This usually works very well, but an exclusive focus on individual characteristics will not suffice when it comes to explaining the variation in the social actions of individuals. More than 40 years ago, the American sociologist Allen H. Barton (1968) already wrote a clear critique of purely individually oriented research, determining that this systematically hides the social environment - the so-called context - of an individual.

But as usually practiced, using random sampling of individuals, the survey is a sociological meat grinder, tearing the individual from his social context and guaranteeing that nobody in the study interacts with anyone else in it. It is a little like a biologist putting his experimental animals through a hamburger machine and looking at every hundredth cell though a microscope; anatomy 
and physiology get lost, structure and function disappear, and one is left with cell biology. (Barton, 1968, 1)

Barton's contribution exemplifies the need to consider not only characteristics of individuals but also their social environment. Individuals' attitudes and behaviour are not located in an isolated space unrelated to the environment surrounding them and how they perceive it. According to general theoretical approaches to social action (Coleman, 1990; Esser, 1999), individual behaviour cannot be traced back to individual characteristics of persons alone, but should also be considered as an outcome of the conditions of the environment in which a person is socially embedded (Esser, 1999). Consequently, the logic of situation has to be taken into account. The context can affect people insofar as even people with similar individual characteristics (e.g. similar income, or educational level) may behave and act differently if they belong to different social contexts (Engel \& Simonson, 2004). Vice versa, within one and the same context, persons with different personal characteristics can act and behave in a similar way. Explanations of context effects are based on the assumption that individual behaviour is mediated primarily by the embeddedness of a person in specific contextual social interactions (e.g. Burbank, 1995). Accordingly, members of sport clubs are nested within their club, and members of each club share certain indubitable similarities that are distinctive for only this club and might not be shared with other clubs. These specific characteristics distinguish them as a group from members of other clubs. Contextual information transfers do not just take place in personal interactions (face to face). Contextual influences can also take place through observation and the reconstruction of signs by which other people express their (sporting and social) action orientation within the club, by perception of (sport club-)political activities, up to the access to club services or facilities and so forth. Therefore, models that take into account both contextual and individual influences on individual attitudes and behaviours provide a better description of social reality than models that include only context aspects or only individual characteristics (e.g. Pötschke, 2006). Therefore, context analysis can contribute to a deeper understanding of individual behaviour (e.g. Todd et al., 2005); and if there are pertinent theoretical considerations and the data structure allows it, the context should be considered in the analysis.

\section{The social context of sport clubs as an interest community}

Based on these general assumptions about the relevance of context conditions, the multilevel framework developed here assumes that both individual factors and the specific structural conditions of a sport club influence a member's action and individual commitment to the club. Thus, the next step is to conceptualise the organisational context sport club in more detail. The basis for actor-theoretical thinking is - according to Giddens (1984) and his structuration theory - the presumption that social acting and social structures are in a constant reciprocal connection. Accordingly, sport clubs 
change due to the ongoing reciprocal interplay between the members' social acting and the clubs' structures. In this context, voluntary sport clubs can be characterised in terms of their specific social structure as interest communities (Coleman, 1974). This means that they have an organisational logic based on self-organisation and the pooling of resources (cf. Coleman, 1974; Vanberg, 1978). Social acting within a sport club is then marked by the members combining their resources in order to realise their shared interests. Their aim is to produce certain club goods, and to provide these goods exclusively for the benefit and interests of the members (Weisbrod, 1975). In order to produce the club goods collectively, club members are prepared to deliver not only financial resources (membership fees) but also all temporal resources (work donations) to their club (e.g. Sandler \& Tschirhart, 1980). Hence, the production of the club goods depends on actions based on reciprocity and relations based on solidarity among club members (i.e. the consumer and the producer adopt the same role). The norms and values needed to collectively produce the club goods can be defined as an unwritten contract involving individual beliefs about reciprocal or solidaritybased obligations between a sport club and its members.

\section{Multilevel model of member commitment in sport clubs}

Due to the complexity of the parameters that may influence the membership decisions of individuals, the logic of selection was conceptualised in terms of the economic theory of human behaviour (Becker, 1993; 1996), which expands the applicability of economic choices to non-market domains as well. The limits of purely purposiverational actions are rarely denied any more, and increasingly soft factors as well as institutional circumstances are being taken into account in economic decision-making models (Frey, 1999; Opp, 1991).

According to the economic theory of behaviour, people are confronted with decisions on how to use their limited resources (of time and money) to maximise their utility. A membership decision to be part of an interest community is linked to the extent to which a member's interests are met by the offers and incentives of the organisation. Thus, membership in a sport club (as an interest community) implies the investment of time (e.g., voluntary engagement) and money (e.g., membership fees) to the sport club in order to satisfy the member's interests (e.g. consumption of sports and social services at a reasonable price, social contacts, appreciation by other people etc.). If the members' club-related experiences do not deliver these returns, then individuals are likely to leave the club in pursuit of more attractive organisational settings for their leisure activities. Therefore, the destabilisation of member commitment can be viewed as the result of a negative outcome of cost-utility considerations, due to diverging individual interests and/or organisational incentive structures. Furthermore, the broader the available leisure-time alternatives, the greater the opportunity costs 
of club membership (e.g., Heinemann, 1995), which makes it less profitable to invest one's limited time and money into club membership.

Gender and age are included in the economic model because, on the one hand, time is an age- and gender-dependent variable, since age- and gender-related tasks (childrearing, career, retirement) may influence time and money budgets. On the other hand, it should be considered that individual characteristics (age, gender, human capital) may influence individual preferences and priorities towards club membership, and ultimately determine the individual utility and proposed alternatives (Lavoie, 2004). Furthermore, it is assumed that the extent of the individual utility of club membership depends on an individual's club-related experiences and relationships (Braun \& Nagel, 2005; Nagel, 2006a). Thus, member-specific factors should be considered in the economic model.

In this context, the concept of consumption capital provides valuable explanations from an economic perspective. Consumption capital is an economic construct and can be understood to represent the accumulated knowledge and importance of goods, depending on the consumption intensity of the specific good (Stigler \& Becker, 1977). The greater the club-related consumption capital, the greater the utility resulting from club membership and the less attractive the alternatives, because the lost benefits of club membership may be difficult to compensate adequately. It can be assumed that the consumption capital of club members is evident to various degrees and is closely connected particularly to the duration and intensity of club membership. In other words, due to the accumulated consumption capital, a sport club can become an (indispensable) part of one's life and an important identity vehicle for club members, as a result of which other alternatives are not considered.

According to the logic of situation, individual utility influencing the individual decision processes are related to contextual conditions in which a person is socially embedded (Esser, 1999). Therefore, structural characteristics of sport clubs have to be considered in the economic decision model. Thus, sport clubs with their specific structure of opportunities (such as possibilities for collective sport arrangements), their cultural references (their unique traditions, values and norms), and their social references (such as identification, social networks) create several incentives that - in line with individual preferences - become parameters of the individual member's actions (Nagel, 2006b). Accordingly, structural conditions running contrary to members' interests can be seen as destabilising factors, because these threaten the utility of the membership in an interest community and at the same time reduce the costs of non-membership.

First, it would seem that club size might be a relevant factor. Club size is a proxy for the degree of homogeneity or heterogeneity in the interests within a club; members' interests are typically more diverse in larger clubs (e.g., Klenk, 2011; Wicker, Breuer, Lamprecht \& Fischer, 2014). At the same time, the size of the organisation 
controls the relationship between resource investment and expected benefit in connection with the creation of club assets (Buchanan, 1965). Within the sport club, members produce club goods through their voluntary activities, the benefits of which decrease for the individual the more individuals participate in this goods. Hence for every club an ideal size can be assumed to exist at which the individual members of the organisation are able to derive maximum satisfaction of their interests from the resources they invest in creating club goods. Above a certain size of the group participating in the club goods, the added benefit for the individual is lower than the additional production costs incurred by him or her (Pierdzioch, Emrich \& Balter, 2013).

A club's strategic orientation is also decisive for the realisation of the interests of its members. Clubs with a stronger orientation towards solidarity are characterised by a stronger sense of collective shared solidarity within the club and commitment to the club's interests (e.g., Braun \& Nagel, 2005), and this increases the probability of satisfying individual interests in terms of identification and solidarity (e.g., Nagel, 2006a; 2006b). Service-oriented clubs are more likely to be characterised by increasing professionalisation and service industry orientation. On the one hand, such clubs provide a broader range of services and offers, and therefore, the possibility of satisfying individual interests of club members increases. On the other hand, the probability of fewer collective shared values and more divergences between individual and collective interests increases (e.g., Horch, 1998; Nagel, 2006b).

The efficiency of the sport club in relation to the satisfaction of its members' interests depends on the level of its resources. Due to the latent resource constraints of sport clubs (Wicker \& Breuer, 2011), clubs cannot serve all interests equally. Allocation problems can then lead to personal as well as interpersonal divergences or conflicts of interests (Heinemann, 2004; Klenk, 2011). Such resource constraints can also restrict the development opportunities of a sport club (e.g. creation of new sport provisions) in response to changed interests and quality expectations among its members (Wicker \& Breuer, 2013). Finally, the question of stability of membership is also closely linked to what alternative provisions are available (Blau, 1994). Urban areas offer a broader range of alternatives for recreation than rural areas. Under these conditions, the decision to leave a sport club is less costly for a member (in terms of adequate sport-related and social alternatives). Hence, in rural areas the probability of finding an alternative after resigning from a club is lower, because sport clubs continue to have a monopoly for certain sports offers in terms of a limited geographical catchment area. Furthermore, sport clubs in rural areas are expected to display a stronger community character due to their greater proximal value as social institutions (Nagel, 2006b). This increases the probability that they will satisfy individual values of identification and solidarity.

Up to this point, club-specific structural conditions have been considered in direct connection with the individual benefits. However, beyond this, these struc- 
tural conditions may be assumed to have an influence on individual expectations and preferences, and to determine the relevance of individual parameters in the decisionmaking process. This could therefore lead to shifts within the individual cost-benefit ratio, which in turn has consequences for the club membership decision. This raises the question, to what extent differences in the importance of individual factors influencing member commitment can be explained by context characteristics (cross-level effects).

In sum, the membership decision (stay or leave the club) is conceptualised as being a result of factors operating on different levels. This means that member commitment is not only influenced by individual factors but also affected by structural factors of the club. Hence, the multilevel framework developed incorporates the fact that club members (e.g., club member i) are embedded (nested) within specific sport clubs (e.g., sport club j).

Organisational level (sport club)

Individual level (club member)
Structural characteristics of sport club $j$ situational characteristics resource capacities strategic orientation

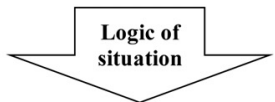

Characteristics of club member $i$ in sport club $j$ socioeconomic factors memberspecific factors

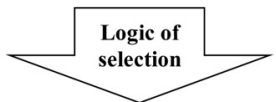

Club membership of club member $i$ in sport $c l u b j$

Figure 1: Multilevel framework for explaining member commitment in sport clubs (own diagram according to Wicker \& Hallmann, 2013)

\section{Method}

\section{Data collection}

The multilevel framework for analysing the relationship between club structures and member actions is characterised primarily by combining member and club data. To obtain a large and comprehensive database, our study draws on data from 45 Swiss and 8 German sport clubs. ${ }^{1}$ Since it is desirable to have a large variety of structural

1 To increase the structural variety on a contextual level, while on the other hand generating a higher number of cases (on a contextual and individual level), German sport clubs were 
conditions on the contextual level, the sampling procedure was designed to encompass different types of structure in sport clubs in terms of the number of members, personnel structure, divisions and types of sport, and so forth. The first step was to obtain club-specific structural data from club managers (presidents, technical directors) with a paper-and-pencil questionnaire. The next step was to gather individuallevel data from club members in an online survey. The sport clubs sent an email newsletter to all members ( $>16$ years) who had valid email addresses. This contained a link to a questionnaire asking interested club members to answer items on membership in their sport club. After data cleaning, the study sample contained a total of 1,895 participants. The response rate within the sport clubs varied from $5 \%$ to $30 \%$.

The majority of respondents $(67.3 \%)$ were male. This unequal gender distribution may be due to women still being underrepresented in sport clubs (Lamprecht et al., 2012). Regarding the age distribution, it is important to note that only club members over the age of 16 years were questioned in our study, so that deviations from the population exist. The age distribution ( $M=36.2$ years; $S D \pm 15.9)$ is as follows: $16.7 \%$, up to 20 years; $43.1 \%, 21-40$ years; $29.8 \%$, $41-60$ years; and $10.4 \%$, over 61 years. The duration of club membership ( $M=15.7$ years; $S D \pm 13.1)$ is distributed as follows: $27.5 \%$, up to 5 years; $16.1 \%, 6-10$ years; $25.4 \%, 11-20$ years; and $31.0 \%$, over 21 years. In addition, $58.3 \%$ of the respondents engaged in voluntary activity in their club, and $83.8 \%$ of the club members are/were active in sports competitions.

\section{Operationalisation}

The operationalisation of the stability of membership (as dependent variable) was based on existing concepts of commitment research (e.g., Meyer, Allen \& Smith, 1993). Club members were asked to what extent over the past few months (before the survey) they had been thinking of resigning their club membership. A total of $62.6 \%$ answered this question with no, $26.4 \%$ sometimes, and $11.1 \%$ frequently or often. This means that approximately two-thirds of the members can be characterised as loyal to their club and about one third as potential dropouts. Not everyone who thinks about leaving the club will actually quit their membership, but the probability of an exit may well be significantly higher among members who have already considered such a decision.

The independent variables on the individual level were operationalised as follows: In a first step, individual restrictions in terms of time and money were measured using the variables net income per month and working hours. Variables that determine restrictions in time and money, and influence the individual preferences (utility) of club membership were measured via age, gender, children within the club, and

included in the analysis. Although they are part of different sport systems, both Swiss and German sport clubs can be integrated in our study because they show a great deal of structural similarity apart from club size (Wicker et al., 2014). 
educational level. Furthermore, member-specific variables were considered. Satisfaction of one's individual interests is essential for club membership. Therefore, the concept of member satisfaction was transferred to sport clubs. Member satisfaction is an outcome based on the cognitive and emotional evaluation of the relationship between members' expectations and their experience of the club situation. Member satisfaction is achieved when the expectations are met (e.g. Dürr, 2009; Nagel, 2006a; 2006b). For the operationalisation of members' club-related experiences and relationships, variables were chosen that represent duration and intensity of club membership. We have included the variables membership duration, competition experiences, and voluntary engagement. For the operationalisation of the intensity of club membership, the variables perceived collective solidarity and identification with the club were also taken into account (see Nagel, 2006a; 2006b). This scale was based on conceptual ideas about aspects of the social and emotional attachment to sport clubs (Cuskelly \& Boag, 2001; Engelberg, Skinner \& Zakus, 2006; see Meyer et al., 1993, for basic treatment), aspects of solidarity and collective interests in sport clubs (Braun \& Nagel, 2005), and different frameworks of sport club culture (Heinemann, 2004).

The operationalisation of independent variables on the organisational level is in line with sport club studies (e.g. Wicker et al., 2014; Lamprecht et al., 2012). Here we differentiate between situational variables (club age, number of members, number of divisions, settlement structure of the club), resource-specific variables (household budget, member fee structure, human resources), and variables representing the strategic orientation of a club. Additionally, with regard to theoretical concepts of club theory (Buchanan, 1965), the squared term for the variable members is used to capture the effect that the benefits of club goods do not steadily increase with increasing number of members.

A detailed overview of the operationalisation of all dependent and independent variables (on both individual and organisational level) is given in table 1, and table 2 includes an overview of all descriptive statistics. 
Table 1: Variables for analysing member commitment and their operationalisation

\begin{tabular}{|c|c|}
\hline Variable & Operationalisation \\
\hline \multicolumn{2}{|c|}{ Operationalisation variables on individual level } \\
\hline $\begin{array}{l}\text { Dependent variable } \\
\text { Stability of club membership } \\
\text { (Intention to leave) }\end{array}$ & $\begin{array}{l}\text { "Have you thought about quit your club membership in recent times?" } \\
(1=\text { "often" to } 5=\text { "never") }\end{array}$ \\
\hline $\begin{array}{l}\text { Socio-economic factors } \\
\text { Gender } \\
\text { Age } \\
\text { Human capital }\end{array}$ & $\begin{array}{l}\text { Dummy; } 1=\text { male } \\
\text { Number of years of life ( }>16 \text { years) } \\
\text { Level of education: } 1=\text { Secondary school level I; } 2=\text { Secondary } \\
\text { school level II, } 3=\text { Higher education (tertiary) }\end{array}$ \\
\hline Income & $\begin{array}{l}\text { Personal net income in CHF per month: } 1 \leq 3,000 \mathrm{CHF} ; 2=3,001- \\
4,500 \mathrm{CHF} ; 3=4,501-6,000 \mathrm{CHF} ; 4>6,001 \mathrm{CHF}\end{array}$ \\
\hline Working time & $\begin{array}{l}\text { Working hours per week: } 1=\text { None, part-time II }(\leq 50 \%), 2=\text { Part-time } \\
\text { I }(50-90 \%), 3=\text { Full-time }(>90 \% \text { and more })\end{array}$ \\
\hline \multicolumn{2}{|l|}{ Membership-related factors ${ }^{\mathrm{a}}$} \\
\hline Children belonging to club & Dummy; $1=$ Yes $(\leq 16$ years $)$ \\
\hline Member satisfaction (global) & $1=$ very dissatisfied to $5=$ very satisfied $(z$-standardised $)$ \\
\hline Duration of club membership & Number of membership years \\
\hline Competition experiences & Dummy; $1=$ Yes \\
\hline Identification with the club & Index from 5 Items $(z \text {-standardised })^{\mathrm{b}}$ \\
\hline Perceived (collective) solidarity & Index from 4 Items $(z \text {-standardised })^{\mathrm{b}}$ \\
\hline Volunteering in the club & Dummy; 1 = Yes (formal and sporadically) \\
\hline \multicolumn{2}{|r|}{ Operationalisation variables on context level } \\
\hline \multicolumn{2}{|l|}{ Situational characteristics } \\
\hline Members & Number of club members \\
\hline Members $^{2}$ & Squared number of club members (= members*members) \\
\hline Divisions & Number of divisions with different sports \\
\hline Settlement structure of the club & $1=$ rural $; 2=$ agglomeration; $3=$ urban; $4=$ city \\
\hline \multicolumn{2}{|l|}{ Resource-specific characteristics } \\
\hline Household budget ${ }^{c}$ & Household budget p.a. in CHF \\
\hline Member fee structure ${ }^{c}$ & Average member fees p.a. in CHF (Adults) \\
\hline Personal resources & Resource "voluntary work": $1=$ no problems to $3=$ big problems \\
\hline \multicolumn{2}{|l|}{ Strategic orientation of $c l u b^{\mathrm{d}}$} \\
\hline Supporting competitive sports & $1=$ not important to $5=$ important \\
\hline Supporting grassroots sports & $1=$ not important to $5=$ important \\
\hline Maintaining tradition & $1=$ not important to $5=$ important \\
\hline Supporting sociability & $1=$ not important to $5=$ important \\
\hline Being open for new developments & $1=$ not important to $5=$ important \\
\hline Supporting external cooperation & $1=$ not important to $5=$ important \\
\hline Hiring paid staff & Dummy; 1 = paid staff \\
\hline
\end{tabular}

a After controlling for multicollinearity, the variable "activity years" was not included in the model.

${ }^{\mathrm{b}}$ (1) Identification with the club (Index: $M=4.05 ; S D=0.77$; Cronbach's $\alpha=0.83$ ): "I feel that I belong to the club", "I like being in our club", "I enjoy attending our club events", "I am proud to be able to say that I belong to this club", "I often discuss club affairs with other members". (2) Perceived (collective) solidarity (Index: $M=4.07 ; S D=0.82$; Cronbach's $\alpha=0.85$ ): "We make sure we deal with each other in a frank and friendly way in our club", "There is a good atmosphere in our club", "We openly discuss problems in our sport club", "We place great value on working together as a team".

Respondents assessed each item on a 5-point scale ranging from 1 (not at all true) to 5 (completely true). ${ }^{\mathrm{c}}$ Because this study included sport clubs from different countries, the household budget and member fee structure of German sport clubs was converted into Swiss currency $(1 €=1.22 \mathrm{CHF})$.

${ }^{\mathrm{d}}$ The analysis was not based on classifying the strategic orientation of clubs according to aggregated structure profiles but used scores on single characteristics. These were tested for consistency. Correlations did not reveal any inconsistencies in strategic orientations. 
Table 2: Descriptive statistics for the independent variables on the individual and context level

\begin{tabular}{|c|c|c|}
\hline \multicolumn{2}{|l|}{ Variables on individual level } & \multirow{3}{*}{$\begin{array}{l}\% \\
67.3 \\
32.7\end{array}$} \\
\hline \multirow[t]{2}{*}{ Gender } & Male & \\
\hline & Female & \\
\hline \multirow[t]{2}{*}{ Children belonging to club } & Yes & 14.5 \\
\hline & No & 85.5 \\
\hline \multirow[t]{2}{*}{ Competition experiences } & Yes & 83.8 \\
\hline & No & 16.2 \\
\hline \multirow[t]{2}{*}{ Volunteering in the club } & Yes & 58.3 \\
\hline & No & 41.7 \\
\hline \multirow[t]{3}{*}{ Human capital } & Secondary school level I & 10.4 \\
\hline & Secondary school level II & 47.9 \\
\hline & Higher education (tertiary) & 41.7 \\
\hline \multirow{4}{*}{ Income } & $\leq \mathrm{CHF} 3,000$ & 28.6 \\
\hline & CHF 3,001 - 4,500 & 22.5 \\
\hline & CHF $4,501-6,000$ & 23.6 \\
\hline & $>$ CHF 6,001 & 25.3 \\
\hline \multirow{3}{*}{ Working time } & None, part-time II $(\leq 50 \%)$ & 19.2 \\
\hline & Part-time I $(50-90 \%)$ & 15.3 \\
\hline & Full-time ( $>90 \%$ and more $)$ & 65.5 \\
\hline \multicolumn{2}{|l|}{ Variables on individual level } & \\
\hline Age in years & $37.5(17.4)$ & \\
\hline Duration of club membership in years & $15.7(13.0)$ & \\
\hline Member satisfaction (global) & $3.87(1.08)$ & \\
\hline Identification with the club & $4.05(0.77)$ & \\
\hline Perceived (collective) solidarity & $4.07(0.82)$ & \\
\hline \multicolumn{2}{|l|}{ Variables on context level } & $\%$ \\
\hline \multirow[t]{4}{*}{ Settlement structure of the club } & Rural & 10.0 \\
\hline & Agglomeration & 29.7 \\
\hline & Urban & 29.3 \\
\hline & City & 31.0 \\
\hline \multirow[t]{3}{*}{ Personal resources } & No problems & 33.5 \\
\hline & Medium problems & 26.0 \\
\hline & Big problems & 40.5 \\
\hline \multirow[t]{2}{*}{ Paid staff } & Yes & 52.1 \\
\hline & No (only volunteers) & 47.9 \\
\hline Variables on context level & \multicolumn{2}{|l|}{ Mean $(\mathrm{SD}) / \%$} \\
\hline Members & \multicolumn{2}{|l|}{$747.6(1,361.2)$} \\
\hline Members $^{2}$ & $2,412,512.38$ & \\
\hline Divisions & $5.19(8.4)$ & \\
\hline Household budget & $226,006.7(58,614.4)$ & \\
\hline Member fees p.a. in CHF (Adults) & $218.6(132.1)$ & \\
\hline Supporting competitive sports & $\begin{array}{l}4.03(.69): 2.8 \%=\text { no } \\
\text { partly important. } 22.2\end{array}$ & $\begin{array}{l}\text { mportant, } 13.7 \%=\text { neither } / \text { nor, } 61.3 \%= \\
=\text { important }\end{array}$ \\
\hline Supporting grassroots sports & $\begin{array}{l}4.20(0.93): 2.7 \% \text { not } \\
=\text { neither } / \text { nor, } 36.0 \%\end{array}$ & $\begin{array}{l}\text { nportant, } 1.5 \%=\text { less important, } 14.5 \% \\
\text { partly important, } 45.3 \%=\text { important }\end{array}$ \\
\hline Maintaining tradition & $\begin{array}{l}3.67(0.97): 3.9 \% \text { not } \\
=\text { neither/nor, } 44.8 \%\end{array}$ & $\begin{array}{l}\text { nportant, } 6.4 \%=\text { less important, } 26.7 \% \\
\text { partly important, } 18.2 \%=\text { important }\end{array}$ \\
\hline Supporting sociability & $\begin{array}{l}4.04(0.94): 6.8 \%=1 \\
25.6 \%=\text { partly impor }\end{array}$ & $\begin{array}{l}\text { important, } 27.8 \%=\text { neither } / \text { nor, } \\
\text { nt, } 39.6 \%=\text { important }\end{array}$ \\
\hline Being open for new developments & $\begin{array}{l}4.23(0.88): 3.2 \%=1 \\
=\text { partly important, } 42\end{array}$ & $\begin{array}{l}\text { important, } 16.0 \%=\text { neither } / \text { nor, } 38.7 \% \\
\%=\text { important }\end{array}$ \\
\hline Supporting external cooperation & $\begin{array}{l}3.41(0.95): 2.3 \% \text { not } \\
=\text { neither/nor, } 37.6 \%\end{array}$ & $\begin{array}{l}\text { nportant, } 18.2 \%=\text { less important, } 30.4 \% \\
\text { partly important, } 11.5 \%=\text { important }\end{array}$ \\
\hline
\end{tabular}




\section{Data analysis}

The analysis of contextual influences is associated with hierarchical data structures. Hierarchical data structures exist when the units of analysis are usually individuals (at a lower level) who are nested within contextual units at a higher level (member $\rightarrow$ sport club). When hierarchical data are given, the observations at the individual level are not independent (e.g. Raudenbush \& Bryk, 2002). This means the cases within a context unit are more similar to each other than cases of other different context units. Such a specific data structure requires appropriate analysis strategies that permit insights into the impact and the importance of hierarchically structured affiliations to social contexts. The appropriate method for simultaneously assessing hierarchical data on both individual characteristics and structural factors is multilevel analysis (e.g. Hox, 2002). Multilevel analysis is a method that ensures robust findings from simultaneous estimations of individual and structural data. Indeed, multilevel analysis highlights the effects between variables from several levels and identifies relationships that would remain undetected in conventional regression analyses. It permits a separation of variance into within- and between-level variance while assessing a unique moderating effect such as a cross-level interaction of variables at different levels (Hox, 2002; Snijders \& Bosker, 1999).

In addition, multilevel analyses require large sample sizes, but there is no consensus in the literature regarding the number of cases at the second level. "As usual, it is not precisely known when a sample is large enough to be confident about the precision of the estimates." (Hox, 2002, 45) In general, to achieve accuracy and high power, a large number of groups appears to be more important than a large number of individuals per group (Hox, 2002). In particular, when checking interaction effects, individual and contextual entities need to be sufficiently large (Ditton, 1998). The usual recommendation is therefore to take at least 25 cases at the highest level (the club level) and at least 20 observations within each lower level (the individual level; e.g. Hox, 2002). Accordingly, all sport clubs for which fewer than 20 observations were available were dropped from the analysis. The resulting 42 sport clubs with 1,699 members on the individual level were entered into a multilevel analysis.

Estimates were performed with the restricted maximum likelihood procedure. In line with the logic of multilevel models, we followed the commonly established successive analyses procedure and estimated different multilevel models. 


\section{Results}

\section{Random intercept models}

Our initial assumption was that a member's intention to leave a sport club would vary not only between individual characteristics but also between clubs. First, we estimated a random intercept-only model. ${ }^{2}$ This model calculates the variance proportions of the dependent variables at the individual and contextual levels. Because the intercept-only model - as a so-called empty model (Snijders \& Bosker, 1999) - contained no explanatory variables, the variance terms represent unexplained residual variance. If no variance in the dependent variable could be determined on the second level, structural features of sport clubs indicate no further variance, and thus, multilevel analysis is not required. The estimated random intercept-only model (see model 0 in table 3 ) revealed that the variance of the individual-level residuals ( $\operatorname{Var} r_{i j}$ ) was 1.128 . The variance of the context-level residuals $\left(\operatorname{Var} u_{0_{j}}\right.$ ) was 0.195 . The variance components for both levels are displayed followed by the intraclass correlation coefficient (ICC). The calculated ICC was $p=.147$. This indicates that $14.7 \%$ of the variance could be traced back to differences between the clubs. According to Hox's $(2002,184)$ interpretation for the research area organisation, the ICC can be considered as relatively high. The estimation of the random intercept-only model confirmed our initial assumption, and indicated that a simultaneous estimation of individual and structural characteristics with multilevel analysis was appropriate.

The next step was to enter the differences in the members' commitment at the individual level while controlling structural differences. The random-intercept model documents the estimation of all derived variables at the individual level (see model 1 in table 3). There was a significant effect from four variables at the individual level. A strong identification with the club, a positively perceived collective solidarity, satisfaction with the sport club, and voluntary engagement had a positive influence on member commitment. Other individual factors such as gender, age, duration of membership, children belonging to the club, or competition experiences had no significant influence on member commitment.

To test to what extent the structural conditions within the sport clubs influenced member commitment, we carried out further estimations by successively adding bundles of club-related structural variables to the model (see models $2 a-2 c$ in table 3 ). From a modelling perspective, it is advisable in the following to remove the nonsignificant independent variables to improve the quality of the model (Hox, 2002). Accordingly, only the significant structural variables were transferred into a randomintercept (full) model (see model 3 in table 3). The estimated random-intercept (full)

2 Within these models, the intercepts vary and the scores on the dependent variable for each individual observation are predicted by the intercept that varies across groups. In random intercept models the slopes are fixed (this means the same across different contexts). 
model confirmed the influence of structural variables. Three structural factors had a significant effect and were therefore able to explain club-related differences of member commitment. Stable memberships were more probable in rural sport clubs and in clubs hat explicitly supported sociability. Other structural factors had no significant influence.

The approach for assessing the model indicated an acceptable model fit. The comparison with the deviance values (-2 log likelihood) could be used to assess the validity of the model. Reductions of deviance indicated that the consideration of structural data improved the model valuation, meaning that the model was adapted to the empirical data to a higher degree. Furthermore, the intraclass correlation decreased in relation to variables on the context level. This clarified that the structural conditions included in the analysis could explain the differences between clubs. For changes against the random intercept-only model, in line with Snijders and Bosker (1999), the variance components for each level can be determined. The individual level had a value of $R^{2}=.25$ of the variation between club members with regard to commitment. Furthermore, the model explained $R^{2}=.43$ of the variance between the sport clubs (context level) with regard to member commitment. However, it should be noted that the amount of explainable context variance was substantially smaller (due to lower cases at context level) than the amount of the individual variance.

\section{Random slope model}

So far, the intercept risk of members leaving varied between the clubs, although the slope was fixed across clubs. The next step was to assume that there were also differences between clubs in terms of the strength of the influence of certain independent variables at the individual level (the size of the slopes of the regression coefficients). Additionally, variance components of independent variables were also included in the multilevel model, assuming that certain predictors in relation to club affiliation would affect the dependent variable member commitment differently. A random slopes model is a model in which slopes are allowed to vary between contexts, and the slopes coefficients will therefore differ across groups (clubs). Following we have analysed to what extent the variable identification with the club - as the strongest predictor on an individual level - varies between sport clubs in terms of its influence on member commitment (see model 4 in table 4). ${ }^{3}$ Therefore, we estimated a random slope model within which we also estimated the variance of the coefficient iden-

3 For reasons of efficiency, only a limited number of regression coefficients should be allowed to vary randomly when calculating multilevel models, because otherwise the number of parameters that have to be estimated is too large. The decision which independent variable's variance components are to be released can either be made on the basis of theory, or (as in this case) using an explorative procedure (Hox, 2002). 


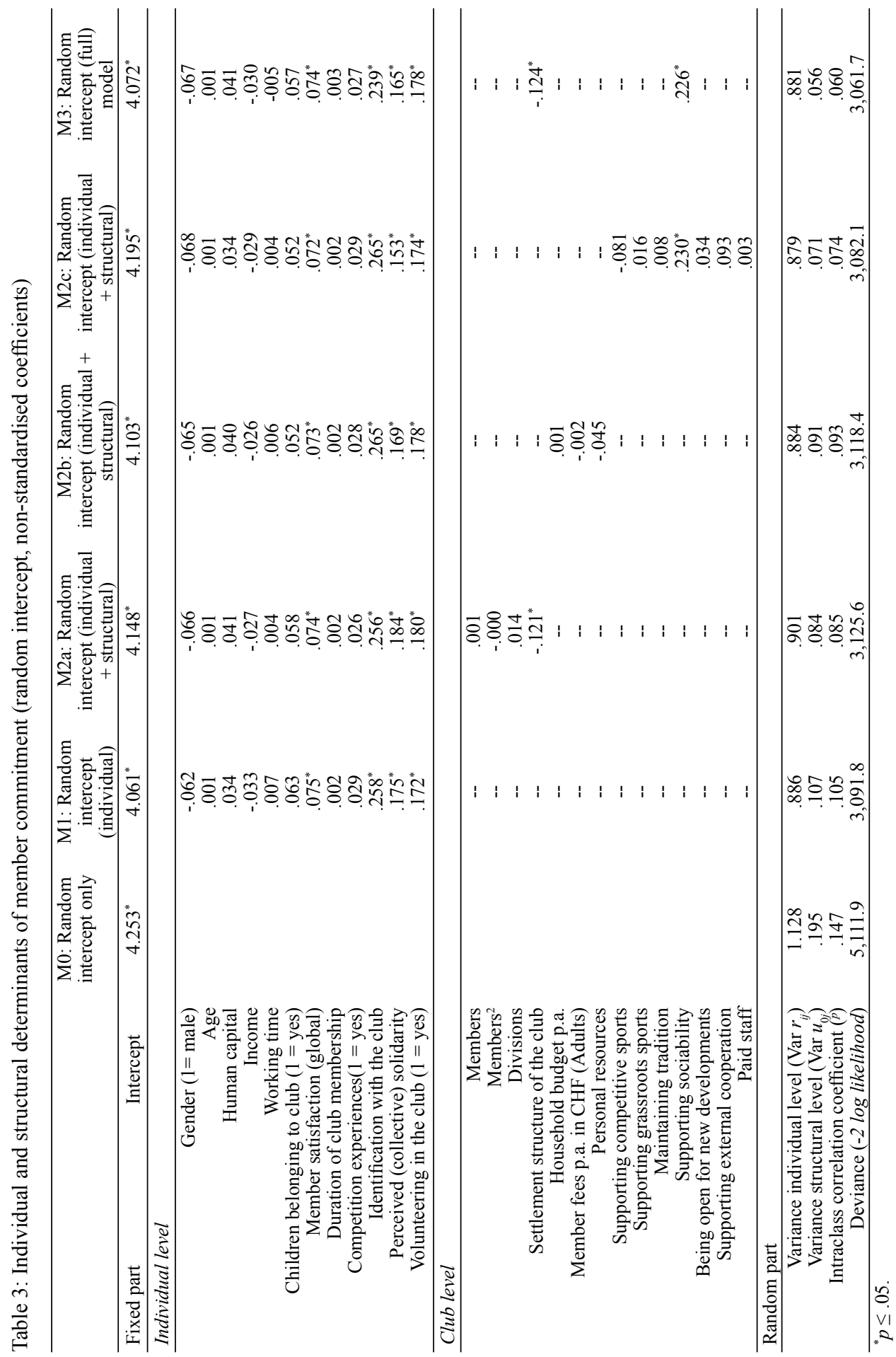


tification ( $u_{1 j}$; group-specific deviation from the average slope) and the covariance between the regression coefficients and constants $\left(\operatorname{cov} u_{0 j}, u_{1 j}\right)$. Results indicated that the variation of the slope parameters was sufficiently large. Therefore, we concluded that there were differences between clubs in the strength of the influence of the independent predictor identification. The covariance $\left(\operatorname{cov} u_{0 j}, u_{1 j}\right)$, can be interpreted as follows: contexts with higher intercept values are associated with greater slope values. Thus, in sport clubs with more stable memberships the positive influence of the variable identification is stronger.

\section{Cross-level analysis}

Finally, cross-level interactions may also be of interest. Multilevel analysis also permits the estimation of possible interactions between individual factors and contextual conditions. Technically, this means that in addition to the independent variables on the individual and contextual levels, the model also included the interactions. The interaction terms are formed - just as in conventional regression analysis - by multiplication of the terms. Hence, this section of the results reports on analyses to what extent both the significant context factors affected the strength of the effect of identification with the club and the risk of leaving. It should be noted here that the cross-level interaction did not affect the predictor identification with the club itself. Instead, these orientations had more or less significant effects on the stability of membership as a function of the level of the context factor - regardless of whether the identification was higher or lower. Results indicated that the context factor sociability exerted an influence on the strength of the effect of identification with the club and the stability of the membership. The relationship between identification and stability of membership is closer in sport clubs with a higher sociability orientation (see model $5 \mathrm{a}$ in table 4). 
Table 4: Individual and structural determinants of member commitment (random slope and cross level interactions)

\begin{tabular}{|c|c|c|c|}
\hline & $\begin{array}{c}\text { Model } 4 \\
\text { Random slope } \\
\text { model }\end{array}$ & $\begin{array}{c}\text { M5a } \\
\text { Random slope with } \\
\text { cross level (1) }\end{array}$ & $\begin{array}{c}\text { M 5b } \\
\text { Random slope with } \\
\text { cross level (2) }\end{array}$ \\
\hline Fixed part & $3.873^{*}$ & $3.840^{*}$ & $3.742^{*}$ \\
\hline \multicolumn{4}{|l|}{ Individual level } \\
\hline Gender $(1=$ male $)$ & -.064 & -.063 & -.063 \\
\hline Age & .001 & .001 & .001 \\
\hline Human capital & .036 & .040 & 037 \\
\hline Income & -.038 & -.032 & -.034 \\
\hline Working time & .007 & .008 & .007 \\
\hline Children belonging to club $(1=$ yes $)$ & .061 & .062 & .061 \\
\hline Member satisfaction (global) & $.071^{*}$ & $.069^{*}$ & $.071^{*}$ \\
\hline Duration of club membership & .002 & .002 & .002 \\
\hline Competition experiences $(1=$ yes $)$ & .024 & .023 & .023 \\
\hline Identification with the club $b^{\mathrm{a}}$ & $.236^{*}$ & $.227^{*}$ & $.225^{*}$ \\
\hline Perceived (collective) solidarity & $.153^{*}$ & $.151^{*}$ & $.152^{*}$ \\
\hline Volunteering in the club $(1=$ yes $)$ & $.165^{*}$ & $.163^{*}$ & $.165^{*}$ \\
\hline \multicolumn{4}{|l|}{ Club level } \\
\hline Settlement structure of the club & -.122 & $-.119^{*}$ & $-.114^{*}$ \\
\hline Supporting sociability & .175 & $.166^{*}$ & $.174^{*}$ \\
\hline \multicolumn{4}{|l|}{ Interaction terms (cross level) } \\
\hline $\begin{array}{r}\text { Supporting sociability } x \text { identification } \\
\text { with the club }\end{array}$ & -- & $.121^{*}$ & -- \\
\hline $\begin{array}{l}\text { Settlement structure of the club } \mathrm{x} \\
\text { identification with the club }\end{array}$ & -- & -- & .008 \\
\hline \multicolumn{4}{|l|}{ Random part } \\
\hline Variance individual level $\left(\operatorname{Var} r_{i j}\right)$ & .876 & .879 & .877 \\
\hline Variance structural level (Var $\left.u_{0 j}\right)$ & .053 & .054 & .054 \\
\hline Variance slope "identification" $u_{1 j}$ & .038 & .037 & .037 \\
\hline Covariance $u_{0 j} u_{1 j}$ & .034 & .035 & .037 \\
\hline Intraclass correlation coefficient $(p)$ & .057 & .058 & .058 \\
\hline Deviance (-2 log likelihood) & $3,053.4$ & $3,049.7$ & $3,057.8$ \\
\hline
\end{tabular}

${ }^{*} p \leq .05$.

${ }^{a}$ Variable (slopes) varies between sport clubs

\section{Discussion}

The multilevel analysis indicates that a stable commitment of members to sport clubs is not just an outcome of individual characteristics. It is also influenced by club-specific structural conditions. The results on the individual level show that, in particular, member-related aspects play a central role in long-term club membership. It becomes clear that the utility and individual gains from club membership depend on the relationship to and the membership experiences in the sport club. The results show that individual expectations regarding the club's provisions and whether these expectations are met are of central importance. Furthermore, the utility of club membership is closely linked to identification and the obligation of solidarity. These findings are consistent with prior findings on member retention in sport clubs (e.g., Nagel, 
2006a). It becomes clear that members adhere to club membership as an established alternative due to the (accumulated) consumption and social capital. It becomes clear that sport clubs are both beneficial organisations for recreational activities and important identity vehicles for individuals, so that the probability of finding a suitable alternative if membership is terminated is considered to be low. In contrast, the variables membership duration, competition activity, children within the club, age, sex, income, working time and human capital do not reveal any systematic influence on member commitment. All in all, it becomes clear that at the individual level, only membership-related factors influence the members' commitment, whereas variables such as age or gender - in contrast to analyses of the recruitment of new members - have no noticeable influence. Results further demonstrate that the inclusion of context factors changes the results only marginally, which confirms the robust influence of the individual features.

As assumed, members' commitment varies between sport clubs. Regarding the relevant context characteristics, the intention to leave is less likely in both rural sport clubs and clubs that support sociability explicitly. Clubs with these structural conditions have more stable memberships, regardless of the individual characteristics of their members. This confirms the assumption that members of urban sport clubs have access to a broader range of attractive recreational as well social alternatives, so that leaving the club is less costly. Furthermore, it shows that the sport club as a place for sociability not only provides values of social interaction and solidarity, but also works as a catalyst for the stability of membership when appropriate opportunities are available. This corresponds with existing findings from the current Swiss sport club report, indicating that sport clubs that support sociability are less threatened by instable memberships (Lamprecht et al., 2012). It seems that the factor sociability represents the valuable core for sport clubs, a real USP (unique selling proposition). This means that opportunities of sociability can promote and strengthen the social cohesion and sense of community within the club, which distinguish them from commercial sport providers. Regarding retention of club members, it seems that it is particularly this cultural orientation of clubs that is important, even though it is often viewed as an outdated feature in processes designed to modernise and standardise club efforts.

Results also show that club size, as a proxy for the degree of homogeneity or heterogeneity in the interests within a club (e.g., Wicker et al., 2014), has no systematic effect on an individual member's decision to remain committed to a club. This indicates that it is not the formal organisational unit of the club that is the focus for the members' commitment but the socially manageable unit of the sport group or the division that then functions as a sort of club within a club. In addition, there are no strong effects of either structural features such as the number of divisions, the degree of professionalisation, or of strategic club orientations such as tradition, being open 
for new developments, or supporting cooperation. This is surprising when it is considered that maintaining club traditions tends to be emphasised as a stabilising factor for member commitment, whereas openness tends to be emphasised as a destabilising factor.

Further models of cross level interactions confirmed that context factors do not just affect individual action directly. According to the logic of situation, they also influence the strength of the relation between the individuals and his or her actions. It can be shown that the closeness of the relation between identification and member commitment depends to a greater or lesser extent on the level of the factor sociability. Accordingly, in clubs that are based more on solidarity, identification is more relevant for member commitment; whereas in more service-oriented clubs, this relation is not expected to be so strong. Hence, sport clubs cannot be understood as an obsolete model in terms of the erosion of traditional community-related norms and forms of solidarity. However, club as an alternative form of organisation still provides incentives for pooling individual interests - something that cannot be found so clearly in other contexts of sport. Therefore, sport clubs still have a high priority as an institution that fulfil valuable social functions in times of crisis in society.

The study shows that economic behaviour theory can make a useful contribution to explaining and analysing the individual membership decision processes in sport clubs (logic of selection) that are influenced by individual and structural factors. Nevertheless, some limitations need to be considered. First, our analysis focused on intention to leave as a measure of member commitment. Future studies should include former club members such as dropouts during the previous 12 months. Second, the pool of independent variables at the individual level should be refined. In particular, further time constraints such as alternative (e.g. sport-related or non-sport-related) leisure-time pursuits should be integrated. Third, the structural variables used in the analysis do not demonstrate sufficiently large differences between clubs. Perhaps our selection was too homogeneous. Therefore, further studies should recruit larger samples, especially at the context level. In addition, the underlying data structure of the clubs is based on self-reports from club officials, so that we cannot rule out, for example, differences between intended strategic orientations and how they are actually perceived by members. Finally, further research in other sport systems with different structural conditions is needed in order to validate these results and to gain more generally applicable findings. 


\section{References}

Barton, A. H. (1968). Bringing society back in. Survey research and macro-methodology. American Behavioral Scientist, 12, 1-9.

Becker, G. S. (1993). Der ökonomische Ansatz zur Erklärung des menschlichen Verhaltens [Economic explanation of human beahavior] ( $2^{\text {nd }}$ ed. $)$. Tübingen: Mohr.

Becker, G. S. (1996). The economic way of looking at behavior: The nobel lecture. Stanford, CT: Hoover.

Blau, P. M. (1994). Structural contexts of opportunities. Chicago, IL: University of Chicago Press.

Braun, S. \& Nagel, M. (2005). Zwischen Solidargemeinschaft und Dienstleistungsorganisation. Mitgliedschaft, Engagement und Partizipation im Sportverein [From community solidarity to service organization: Membership, commitment, and participation in sport clubs]. In T. Alkemeyer, B. Rigauer, \& G. Sobiech (Eds.), Organisationsentwicklungen und De-Institutionalisierungsprozesse im Sport [Organisational development and de-institutionalisation processes in sport] (123-150). Schorndorf: Hofmann.

Breuer, C., Wicker, P. \& Feiler, S. (2014). Empirische Analyse zur Entwicklung der Strukturen in Sportvereinen [Empirical analysis of the development of the structures in sport clubs]. In A. Rütten, S. Nagel \& R. Kähler (Eds.), Handbuch Sportentwicklungsplanung [Handbook sport development planning] (225-233). Schorndorf: Hofmann.

Buchanan, J. M. (1965). An economic theory of clubs. Economica, 32, 1-14.

Burbank, M. J. (1995). How do contextual effects work? Developing a theoretical model. In M. Eagles (Ed.), Spatial and contextual model in political research (165-178). London: Taylor \& Francis.

Coleman, J. S. (1974). Power and the structure of society. New York, NY: Norton.

Coleman, J. S. (1990). Foundations of social theory. Cambridge, MA: Belknap.

Cuskelly, G. \& Boag, A. (2001). Organizational commitment as a predictor of committee member turnover amongst volunteer sport administrators: Results of a timelagged study. Sport Management Review, 4, 65-86.

Ditton, H. (1998). Mehrebenenanalyse. Grundlagen und Anwendungen des Hierarchisch Linearen Modells [Multilevel analysis. Basics and applications of the hierarchic linear model]. Weinheim: Juventa.

Dürr, F. (2009). Faktoren der Mitgliederzufriedenheit im Sportverein: Bedeutsamkeit von Vereinsbewertungs-Merkmalen für die globale Zufriedenheit sportlich aktiver Mitglieder ohne ehrenamtliches und berufliches Engagement [Factors of member satisfaction in sport clubs: the importance of club-evaluation for the overall satisfaction of active members without voluntary and professional engagement]. Saarbrücken: Südwestdeutscher Verlag für Hochschulschriften.

Engel, U. \& Simonson, J. (2004). Sozialer Kontext in der Mehrebenenanalyse [Social context in multi-level analyses]. In A. Diekmann (Ed.), Methoden der Sozialforschung [Methods of social research] (Special issue 44 of the Kölner Zeitschrift 
für Soziologie und Sozialpsychologie) (303-329). Wiesbaden: VS Verlag für Sozialwissenschaften.

Engelberg, T., Skinner, J. L. \& Zakus, D. H. (2006). Exploring the commitment of volunteers in little athletics centres. Australian Journal on Volunteering, 11, 56-66.

Esser, H. (1999). Soziologie - Spezielle Grundlagen. Band 1: Situationslogik und Handeln [Sociology - Special principles. Volume 1: Situational logic and action]. Frankfurt: Campus-Verlag.

Frey, B. S. (1999). Economics as a science of human behaviour. Towards a new social science paradigm. Boston, MA: Kluwer Academic.

Giddens, A. (1984). The constitution of society. Outline of the theory of structuration. Cambridge, MA: Polity press.

Gratton, C., Liu, D., Ramchandani, G. \& Wilson, D. (2012). The global economics of sport. Oxon: Routledge.

Green, M. (2008). Non-governmental organisations in sports development. In V. Girginov (Ed.), Management of sports development (89-107). London: Elsevier.

Hallmann, K., Wicker, P., Breuer, C. \& Schönherr, L. (2012). Understanding the importance of sport infrastructure for participation in different sports - Findings from multi-level modeling. European Journal of Sport Management, 12, 525-544.

Hallmann, K., Wicker, P., Breuer, C. \& Schüttoff, U. (2011). Interdependency of sport supply and sport demand in German metropolitan and medium-sized municipalities - Finding from multi-level analyses. European Journal of Sport and Society, 8, 65-84.

Heinemann, K. (1995). Einführung in die Ökonomie des Sports [Introduction to sport economics]. Schorndorf: Hofmann.

Heinemann, K. (2004). Sportorganisationen. Verstehen und Gestalten [Understanding and designing sport organisations]. Schorndorf: Hofmann.

Horch, H.-D. (1998). Self-destroying process of sports clubs in Germany. European Journal of Sport Management, 5, 46-58.

Houlihan, B. \& Green, M. (2009). Modernization and sport: The reform of Sport England and UK Sport. Public Administration, 87, 678-698.

Hox, J. J. (2002). Multilevel analysis: Techniques and applications. Mahwah, NJ: Erlbaum.

Jütting, D. H., von Bentem, N. \& Oshege, V. (2003). Vereine als sozialer Reichtum: Empirische Studien zu lokalen freiwilligen Vereinigungen [Associations as social wealth: Empirical studies on local voluntary associations]. Münster: Waxmann.

Klenk, C. (2011). Ziel-Interessen-Divergenzen in freiwilligen Sportorganisationen. Eine akteurtheoretische Analyse der Ursachen und Auswirkungen [Goal-interest divergencies in voluntary sport organisations. An actor theoretical analysis of the reasons and effects]. Hamburg: Czwalina.

Lamprecht, M., Fischer, A. \& Stamm, H.-P. (2012). Die Schweizer Sportvereine - Strukturen, Leistungen, Herausforderungen [Swiss sport clubs: Structures, achievements, challenges]. Zürich: Seismo. 
Lavoie, M. (2004). Post Keynesian consumer theory: Potential synergies with consumer research and economic psychology. Journal of Economic Psychology, 25, 639649.

Meyer, J. P., Allen, N. J. \& Smith, C. A. (1993). Commitment to organizations and occupations: Extension and test of a three-component conceptualization. Journal of Applied Psychology, 78, 538-551.

Nagel, S. (2006a). Mitgliederbindung in Sportvereinen - Ein akteurtheoretisches Modell [Membership retention in sport clubs: An actor theoretical model]. Sport und Gesellschaft, 3, 33-56.

Nagel, S. (2006b). Sportvereine im Wandel. Akteurtheoretische Analysen zur Entwicklung von Sportvereinen [Sport clubs in changing times: Actor theoretical analyses of trends in sport clubs]. Schorndorf: Hofmann.

Nagel, S. (2007). Akteurtheoretische Analyse der Sportvereinsentwicklung - Ein theoretisch-methodischer Bezugsrahmen [Actor theoretical analysis of the development of sports - A theoretical-methodological frame of reference]. Sportwissenschaft, 37, 186-201.

Nichols, G. \& James, M. (2008). One size does not fit all: Implications of sport club diversity for their effectiveness as a policy tool for government support. Managing Leisure, 13, 104-114.

Nichols, G., Taylor, P., James, M., Holmes, K., King, L. \& Garett, R. (2005). Pressures on the UK voluntary sport sector. Voluntas: International Journal of Voluntary and Nonprofit Organizations, 16, 33-50.

Opp, K.-D. (1991). Das Modell rationalen Verhaltens. Seine Struktur und das Problem der ,weichen“ Anreize. [The model of rational behavior. Its structure and the problem of "soft" incentives]. In H. Bouillon \& G. Andersson (Eds.), Wissenschaftstheorie und Wissenschaften [Theory of science and sciences] (105-124). Berlin: Duncker \& Humblot.

Penner, L. A. (2002). Dispositional and organizational influences on sustained volunteerism: An interactionist perspective. Journal of Social Issues, 58, 447-467.

Pierdzioch, C., Emrich, E. \& Balter, J. (2013). Ehrenamt in Sportvereinen und optimale Klubgrösse - Eine kurze Skizze [Volunteering in sports clubs and optimal club size - A brief sketch]. In H. Kempf, S. Nagel \& H. Dietl (Hrsg.), Im Schatten der Sportwirtschaft [In the shadow of sport economics] (181-190). Schorndorf: Hofmann.

Pötschke, M. (2006). Mehrebenenanalyse [Multilevel analysis]. In J. Behnke, T. Gschwend, D. Schindler \& K.-U. Schnapp (Eds.), Methoden der Politikwissenschaft. Neuere qualitative und quantitative Analyseverfahren [Methods of political science. Recent qualitative and quantitative analysis methods] (167-179). Baden-Baden: Nomos.

Putnam, R. (2000). Bowling alone: The collapse and revival of American community. New York, NY: Simon \& Schuster.

Raudenbush, S. W. \& Bryk, A. S. (2002). Hierarchical linear models: Applications and data analysis methods. Thousand Oaks, CA: Sage. 
Sandler, T. \& Tschirhart, J. T. (1980). The economic theory of clubs: An evaluative survey. Journal of Economic Literature, 18, 1481-1521.

Scheerder, J. \& Vos, S. (2010). Sportclubs in beeld. Basisrapporting over het Vlaamse sportclub panel 2009 [The Flemish sports club panel 2009: First results]. Leuven, Belgium: University of Leuven/Research Unit of Social Kinesiology and Sport Management.

Schlesinger, T. \& Nagel, S. (2013a). Individuelle und strukturelle Faktoren der Mitgliederbindung im Sportverein [Individual and structural factors of member commitment in sport clubs]. Sportwissenschaft, 43, 90-101.

Schlesinger, T. \& Nagel, S. (2013b). "Who will volunteer?" Analysing individual and structural factors of volunteering in Swiss sports clubs. European Journal of Sport Science, 13, 707-715.

Snijders, T. \& Bosker, R. (1999). Multilevel analysis: An introduction to basic and advanced multilevel modeling. London: Sage.

Stigler, G. J. \& Becker, G. S. (1977). De gustibus non est diputandum. American Economic Review, 67, 76-90.

Todd, S. Y., Crook, T. R. \& Barilla, A. G. (2005). Hierarchical linear modelling of multilevel data. Journal of Sport Management, 19, 387-403.

van Tuyckom, C. \& Scheerder, J. (2010). A multilevel analysis of social stratification patterns of leisure-time physical activity among Europeans. Science \& Sports, $25,304-311$.

Vanberg, V. (1978). Markt und Organisation. Individualistische Sozialtheorie und das Problem korporativen Handelns [Market and organisation. Individualistic social theory and the problem of corporative action]. Tübingen: Mohr.

Weisbrod, B. A. (1975). Toward a theory of the voluntary non-profit sector in a three sector economy. In E. S. Phelps (Ed.), Altruism, morality and economic theory (171-195). New York, NY: Sage.

Wicker, P. \& Breuer, C. (2011). Scarcity of resources in German non-profit sport clubs. Sport Management Review, 14, 188-201.

Wicker, P. \& Breuer, C. (2013). Understanding the importance of organizational resources to explain organizational problems: Evidence from non-profit sport clubs in Germany. Voluntas, 24, 461-484.

Wicker, P., Breuer, C., Lamprecht, M. \& Fischer, A. (2014). Does club size matter? An examination of economies of scale, economies of scope, and organizational problems. Journal of Sport Management, 28, 266-280.

Wicker, P. \& Hallmann, K. (2013). A multi-level framework for investigating the engagement of sport volunteers. European Sport Management Quarterly, 13, 110-139.

Wicker, P., Hallmann, K. \& Breuer, C. (2012). Micro and macro level determinants of sport participation. Sport, Business, Management: An International Journal, 2, 51-68. 
Wicker, P., Hallmann, K. \& Breuer, C. (2013). Analyzing the impact of sport infrastructure on sport participation using geo-coded data: Evidence from multi-level models. Sport Management Review, 16, 54-67.

Torsten Schlesinger is Senior Lecturer at the Institute of Sport Science of the University of Bern. His research interests relate to sport club development, analysing decision making processes in sport organisations, and human resource management in voluntary sport clubs.

Institut für Sportwissenschaft, Universität Bern, Bremgartenstrasse 145, 3012 Berne, Switzerland

E-mail: torsten.schlesinger@ispw.unibe.ch

Siegfried Nagel is professor at and vice-director of the Institute of Sport Science of the University of Bern. His main fields of interest are sports development and sports organisation research, particularly sport club development, sports participation as well as life course research.

Institut für Sportwissenschaft, Universität Bern, Bremgartenstrasse 145, 3012 Berne, Switzerland

E-mail: siegfried.nagel@ispw.unibe.ch 